\title{
The Gravity of International Crimes as a Challenge to the (Full) Protection of Human Rights before International Criminal Tribunals? A Strasbourg Perspective
}

Christophe Deprez ${ }^{*}$

\begin{abstract}
While it goes undisputed that international criminal tribunals (ICTs) are, in general terms, bound to respect human rights standards, there is no consensus on whether their obligations should be identical in scope to those of national criminal tribunals. Most commentators seem to value the idea of equality in protection for international and domestic defendants alike. Yet, according to others, the human rights obligations of ICTs should be contextualised, that is, adapted to the specificities of international justice - and most critically to the gravity of international crimes. This article seeks to shed some light on this debate. It does so, in particular, by pointing out the intrinsic flexibility of human rights, and by drawing on the practice of the European Court of Human Rights with respect to gravity-based contextualism.
\end{abstract}

\section{Keywords}

Specificity of international criminal justice; contextualism; gravity of international crimes; flexibility of human rights; international criminal tribunals; European Court of Human Rights

\footnotetext{
* Post-doctoral Researcher and Assistant Lecturer at the University of Liège Law School; Visiting Professor at the University of Lille II Law School. The author would like to thank the anonymous reviewer for constructive and valuable comments on an earlier draft [Christophe.Deprez@ulg.ac.be]
} 